\title{
A Rare Etiology of Small Intestinal Obstruction - Solitary Myelogenic Sarcoma of the Small Intestine: CT Findings and a Review of the Literature
}

\section{Lesheng Huang, Jun Chen, Wei Peng, Kaili Cai, Hongyi Li, Jinghua Jiang, Wanchun Zhang, Jiahui Tang, Tianzhu Liu*}

Department of Radiology, Guangdong Hospital of Traditional Chinese Medicine, Zhuhai, China

Email address:

Leshenghuang2008@163.com (Lesheng Huang), 153462964@qq.com (Tianzhu Liu)

${ }^{*}$ Corresponding author

\section{To cite this article:}

Lesheng Huang, Jun Chen, Wei Peng, Kaili Cai, Hongyi Li, Jinghua Jiang, Wanchun Zhang, Jiahui Tang, Tianzhu Liu. A Rare Etiology of Small Intestinal Obstruction - Solitary Myelogenic Sarcoma of the Small Intestine: CT Findings and a Review of the Literature. International Journal of Clinical and Experimental Medical Sciences. Vol. 6, No. 3, 2020, pp. 35-40. doi: 10.11648/j.ijcems.20200603.12

Received: May 11, 2020; Accepted: June 4, 2020; Published: June 16, 2020

\begin{abstract}
Background: Myelocytic sarcoma is a rare extramedullary tumor consisting of immature myeloid cells-granulocytes, mononuclear cells, or both. It usually occurs in patients with acute or chronic myeloid leukemia and is often found in the skin, bone, and lymphatic tissues. Isolated myeloid sarcomas are more uncommon in patients without leukemia in the small intestine. Case presentation: In the present study, a hospitalized case is discussed with intestinal obstruction as the primary symptom. During the CT examination, the local intestinal wall of the jejunum was found to possess ring thickening, intestinal lumen stenosis and proximal intestinal obstruction. The tumor presented with uniform and moderate progressive enhancement. The patient underwent emergency laparoscopic surgery in order to remove the tumor. Immunohistochemical staining on postoperative paraffin sections revealed myelosarcoma. The patient also underwent a bone marrow biopsy to exclude acute and chronic myeloid leukemia and the bone marrow smear indicated normal range. Conclusions: Myeloid sarcoma must be included in the differential diagnosis of small intestinal tumors, although the patient may not have history of leukemia. Radiologists should improve their imaging perception of myelosarcoma.
\end{abstract}

Keywords: Myeloid Sarcoma, Intestinal Obstruction, Tomography, X-ray Computer

\section{Introduction}

Myelocytic sarcoma (MS) is a rare extramedullary malignancy consisting of progenitor granulocytes or immature myeloid cells with an incidence of approximately 2.5-2.9\% worldwide [1-3]. The onset age between children and elderly patients varies [4]. Typically, this disease occurs during the development of acute myeloid leukemia, or chronic myeloid leukemia or during the progression of myelodysplastic syndrome [1-3]. A few cases can also present with peripheral blood or bone marrow disease [1-3]. Extramedullary myeloid cell sarcoma usually occurs in the skin, bone and lymphoid tissues [5-8] and rarely in the small intestine [4]. We present a case of isolated MS in the small intestine with no history of malignancy.

\section{Consent}

The patient agreed to allow the use of her data for writing, teaching and publication purposes.

\section{Case Report}

A 41 year old female patient was admitted to the hospital for more than 2 weeks following repeated defecation. The patient did not have previous history of "blood disease". The physical examination indicated upper left abdomen tenderness and no rebound pain. Specific tumor markers were measured and they exhibited the following values: cell keratin fragment 19: $4.58 \mathrm{ng} / \mathrm{ml}$ (normal range 0-3.3), carbohydrate antigen 125 (CA125): $136.2 \mathrm{U} / \mathrm{ml}$ (normal 
range 0-35). No abnormality was found in the other laboratory biomarkers tested.

The orthostatic plain abdominal film indicated signs of intestinal obstruction. The abdominal CT tip center of the right ileum indicated partial annular thickening of the bowel wall and lumen stenosis, whereas the thickness and length were approximately $13 \mathrm{~mm}$ and $35 \mathrm{~mm}$, respectively. The progressive relatively homogeneous enhancement scan CT value was 51, 76 and $90 \mathrm{HU}$ (hounsfield unit) for the arterial venous phase, the bowel wall and the mesangial side, respectively. The latter two exhibited thickening and increased fat density. In the mesenteric area, multiple enlarged lymph nodes were noted along with proximal ileal apparent effusion, expansion and obstruction of the plane appearing as "waste" sign (Figure 1).

The laparoscopic surgical exploration revealed an intestinal mass 3 meter from the troxton ligament, forming a narrow ring, whereas extensive proximal intestinal dilatation, intestinal wall edema and distal intestinal and colon tumors were also present. "Small intestine partial resection and peritoneal adhesion release (including peritoneum and omentum)" were performed.

The pathological analysis was performed on the excised specimens. Microscopically, a large number of round and ovoid tumor cells were noted that infiltrated the entire intestinal wall. Immunohistochemical staining indicated that $80 \%$ of Ki67 cells were expressed by tumor cells, whereas positive expression was noted for Bcl2, Vimentin, CD38, myeloperoxidase (MPO) and CD117 (figure 2). The final pathological diagnosis was MS.

Based on this diagnosis, bone marrow biopsy was also performed to exclude generalized acute and chronic myeloid leukemia. The bone marrow smear indicated normal range.

Following operation, the patient was treated with chemotherapy and followed up. The patient was in good condition and had no secondary malignant blood disease.
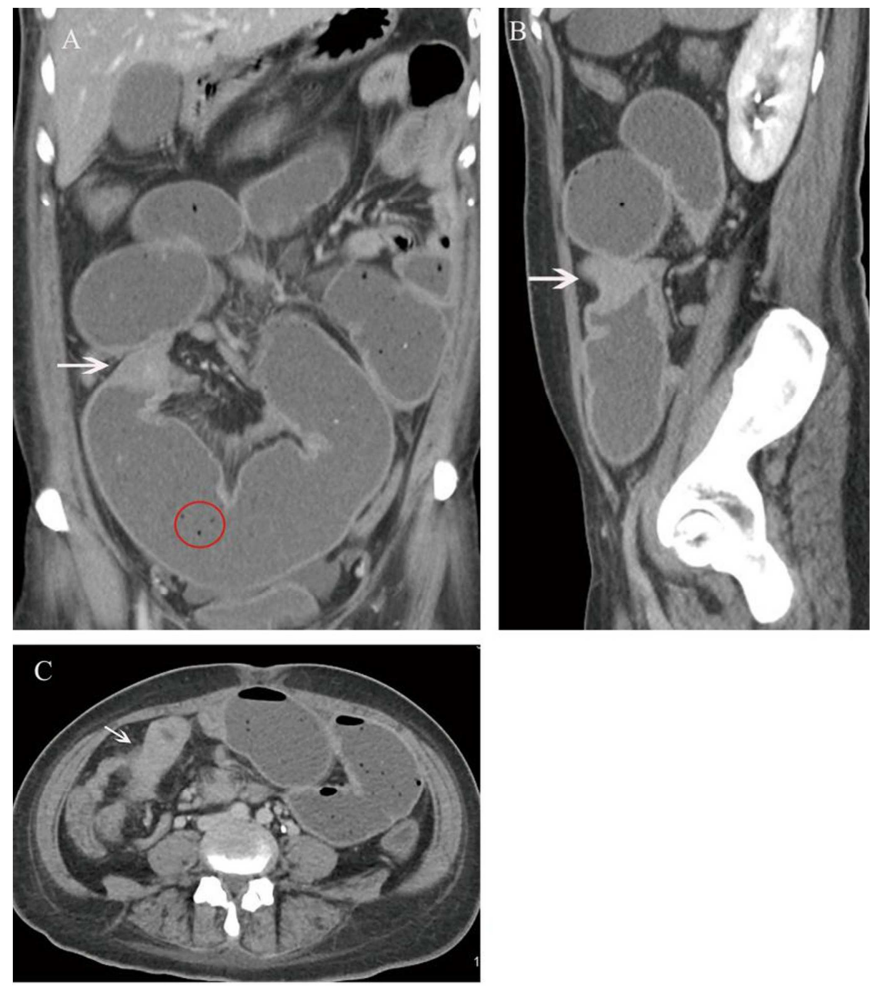

Figure 1. A: Local ileum wall thickening and intestinal cavity narrowing. Contrast homogeneous enhancement (white arrow) also demonstrates obstruction, plane proximal small intestine effusion, dilation and fecal signs (red circle); B: Local ileum wall thickening, intestinal cavity narrowing and contrast homogeneous enhancement (white arrow); C: Local ileum thickening, homogeneous enhancement (white arrow).
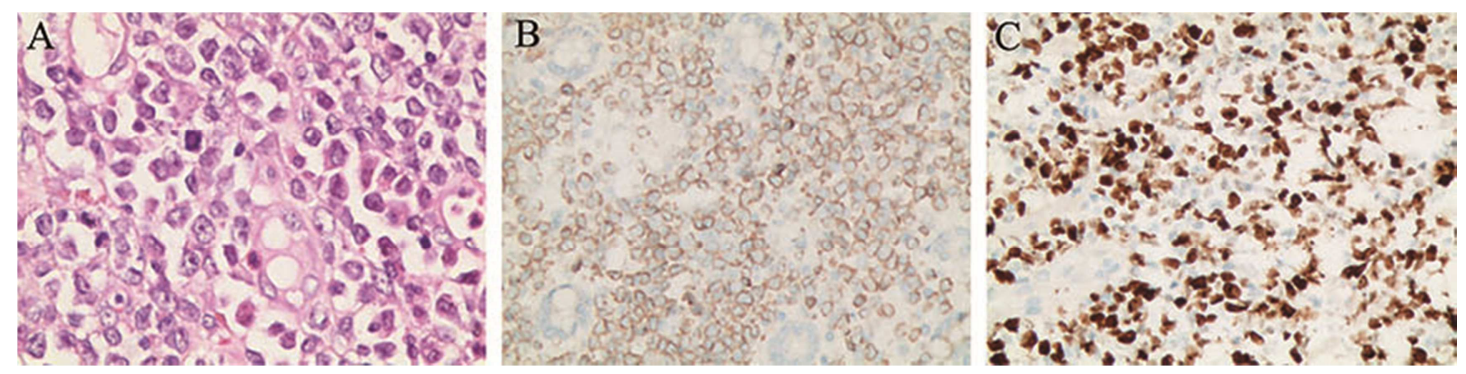

Figure 2. A: Microscopically, a large number of round and ovoid tumor cells can be seen infiltrating the entire wall of the intestine (H\&E staining 40X); B: Immunohistochemical staining: positive for myeloperoxidase (MPO) (Immunohistochemistry 20×); C: Approximately 80\% of Ki67 positive tumor cells were noted (Immunohistochemistry for KI67 20×). 


\section{Discussion}

Although the small intestine accounts for $90 \%$ of the gastrointestinal tract, small intestinal tumors are uncommon, accounting for less than 5\% of all gastrointestinal tumors [9]. Primary small intestinal malignancies account for approximately $2 \%$ of all gastrointestinal malignancies [10]. The proportion of isolated MS occurring in the gastrointestinal tract has been estimated to approximately $6.5 \%[11]$ and the ileum is usually prone to recurrence [12, 13]. Due to its rarity and difficulty in diagnosis, MS is often misdiagnosed as other diseases [14], with a misdiagnosis rate of $25-47 \%$ and the most common misdiagnosis being lymphoma [15-17]. The case reported in the present study involved a tumor that could not be misdiagnosed. In the preoperative imaging report, MS was not listed in the differential diagnosis. When the tumor was explored by laparoscopy, the intraoperative frozen section was also diagnosed as lymphoma and the immunohistochemical staining of the paraffin sections following surgery led to the final diagnosis of MS.

MS, also known as "green tumor" or granulocytic sarcoma, was not named "MS" by the world health organization until 2002 [18]. MS is most commonly seen in patients with malignant blood diseases $[3,8]$ and is present in approximately $1-2 \%$ of patients with acute myeloid leukemia $[1-3,7]$.

$50 \%$ of MS cases are asymptomatic or produce nonspecific manifestations of organ dysfunction or pain related to the mass effect at the affected site. Isolated small intestinal MS is often treated with intestinal obstruction as the first symptom [19]. The majority of the complications include hemorrhage, perforation, necrosis, intussusceptions and obstruction. In the present case, the patient repeatedly stopped venting and defecating for 2 weeks and was accompanied by upper abdominal pain, mild tenderness and no symptoms of fever, anemia, enlarged lymph nodes or any other type of leukemia, which resulted in a considerably difficult clinical diagnosis. Abdominal CT can only indicate local ileal wall ring thickening, intestinal lumen stenosis, progressive homogeneous moderate enhancement, ileal proximal obstruction and enlarged lymph node shadow in the area of the superior mesenteric artery. In the current study, it was found that the CT manifestations of MS were mostly equal to the density of the lesions, with moderate enhancement following enhancement and additional homogeneous enhancement compared with heterogeneous enhancement $[8$, 20, 21]. The CT findings of this case are consistent with those reported in the literature to a large extent. However, some of these clinical signs are not considered a unique sign of MS and similar imaging findings have been reported in inflammatory lesions and lymphoma [22, 23].

Shinagare et al [24] described the magnetic resonance characteristics of 25 patients with 41 different MS localization patterns. The T1-weighted images indicated that the percentage of isosignal cases was $75.6 \%$ and that of low signal cases $24.4 \%$. In the T2-weighted images, the high signal cases corresponded to $95.1 \%$ and the equal signal cases to $4.9 \%$. In another study different results were reported. Meyer et al [20] performed magnetic resonance imaging (MRI) on 28 cases of MS in different parts and found that $60.7 \%$ of the T1-weighted images were isosignals, while $82.1 \%$ of the T2-weighted images were high signals. The enhancement degree of MRI is similar to that of CT. The imaging findings of CT and MRI are not characteristic of MS, which undoubtedly increases the diagnostic difficulty of this disease.

It has been reported that $18 \mathrm{~F}$-fluorodeoxylucose-positron -emission tomography (FDG-PET/CT) is highly sensitive to the diagnosis of extramedullary MS [25-27]. MS has a moderate to high level of glucose intake for FDG, which can be used to provide improved diagnosis for this disease and also assess the situation prior to and following treatment. This can address queries involving the recurrence of the tumor as well as its reduction or enhancement. This is considered an optimal diagnostic method. However, it is not particularly cost-effective and increases the exposure of the patient to radiation. Therefore, it is necessary to identify improved methods to diagnose MS using CT and MR.

We also collected the case reports and comprehensive reports of CT findings of myelosarcoma from 2002 to 2020 for retrospective analysis. The high risk leukemia patients in the small intestine of marrow cell sarcoma are presented with summarized clinical characteristics and CT imaging findings. The data indicated 12 cases ( 4 female, 8 male) involving leukemia with MS, of which 10 were small intestine isolation MS cases. A total of 8 cases included the jejunum and 6 the ileum (table 1).

Table 1. Clinical and CT features of myelogenic sarcoma from literatures of review.

\begin{tabular}{|c|c|c|c|c|c|c|}
\hline \multirow[b]{2}{*}{ Study } & \multirow[b]{2}{*}{ age/sex } & \multirow[b]{2}{*}{ Chief complaint } & \multicolumn{4}{|l|}{ CT finding } \\
\hline & & & $\begin{array}{l}\text { Location and presentation } \\
\text { of lesions }\end{array}$ & $\begin{array}{l}\text { Enhanced } \\
\text { Scanning }\end{array}$ & Changes of lumen & $\begin{array}{l}\text { Presentations of } \\
\text { lymph nodes }\end{array}$ \\
\hline $\begin{array}{l}\text { Palanivelu } \\
\text { et al [28] }\end{array}$ & $52 /$ male & $\begin{array}{l}\text { Abdominal distention } \\
\text { and Pain with a high } \\
\text { fever }\end{array}$ & Mass in the jejunum & $\begin{array}{l}\text { Homogeneous } \\
\text { moderately } \\
\text { enhanced }\end{array}$ & $\begin{array}{l}\text { Narrow bowel } \\
\text { cavity and } \\
\text { proximal intestinal } \\
\text { dilatation }\end{array}$ & ND \\
\hline $\begin{array}{l}\text { Kumar et al } \\
{[19]}\end{array}$ & $55 /$ female & $\begin{array}{l}\text { Left lower abdominal } \\
\text { pain }\end{array}$ & $\begin{array}{l}\text { The wall of the jejunum } \\
\text { thickened irregularly with a } \\
\text { mesenteric mass }\end{array}$ & ND & $\begin{array}{l}\text { Narrow bowel } \\
\text { cavity and } \\
\text { proximal intestinal } \\
\text { dilatation. }\end{array}$ & ND \\
\hline
\end{tabular}




\begin{tabular}{|c|c|c|c|c|c|c|}
\hline \multirow[b]{2}{*}{ Study } & \multirow[b]{2}{*}{ age/sex } & \multirow[b]{2}{*}{ Chief complaint } & \multicolumn{4}{|l|}{ CT finding } \\
\hline & & & $\begin{array}{l}\text { Location and presentation } \\
\text { of lesions }\end{array}$ & $\begin{array}{l}\text { Enhanced } \\
\text { Scanning } \\
\end{array}$ & Changes of lumen & $\begin{array}{l}\text { Presentations of } \\
\text { lymph nodes }\end{array}$ \\
\hline $\begin{array}{l}\text { Yoldaş et } \\
\text { al [29] }\end{array}$ & $44 /$ male & Abdominal pain & $\begin{array}{l}\text { Ileum wall thickened } \\
\text { irregularly }\end{array}$ & $\begin{array}{l}\text { Homogeneous } \\
\text { moderately } \\
\text { enhanced }\end{array}$ & $\begin{array}{l}\text { proximal intestinal } \\
\text { dilatation }\end{array}$ & ND \\
\hline $\begin{array}{l}\text { Lee et al } \\
{[30]} \\
45 / \mathrm{male}\end{array}$ & $45 /$ male & $\begin{array}{l}\text { Intermittent abdominal } \\
\text { cramps }\end{array}$ & $\begin{array}{l}\text { Ileum mass with ileum } \\
\text { intussusception, }\end{array}$ & $\begin{array}{l}\text { Homogeneous } \\
\text { moderately } \\
\text { enhanced }\end{array}$ & ND & $\begin{array}{l}\text { Multiple enlarged } \\
\text { lymph nodes in the } \\
\text { mesenteric root and } \\
\text { perimesenteric } \\
\text { vessels }\end{array}$ \\
\hline $\begin{array}{l}\text { Cicilet et al } \\
{[31]}\end{array}$ & $45 /$ female & $\begin{array}{l}\text { Severe abdominal pain } \\
\text { and vomiting }\end{array}$ & $\begin{array}{l}\text { Eccentric focal ileum wall } \\
\text { thickening }\end{array}$ & $\begin{array}{l}\text { Homogeneous } \\
\text { moderately } \\
\text { enhanced }\end{array}$ & $\begin{array}{l}\text { proximal intestinal } \\
\text { dilatation slightly }\end{array}$ & ND \\
\hline $\begin{array}{l}\text { Wang et al } \\
\text { [32] }\end{array}$ & $23 /$ male & $\begin{array}{l}\text { Intermittent upper } \\
\text { abdominal pain }\end{array}$ & $\begin{array}{l}\text { The wall of the jejunum was } \\
\text { thickened in concentric } \\
\text { circles }\end{array}$ & $\begin{array}{l}\text { Homogeneous } \\
\text { moderately } \\
\text { enhanced }\end{array}$ & ND & $\begin{array}{l}\text { The adjacent } \\
\text { mesenteric soft } \\
\text { tissue mass } \\
\text { wrapped the branch } \\
\text { of the superior } \\
\text { mesenteric artery }\end{array}$ \\
\hline $\begin{array}{l}\text { Aslan et al } \\
{[33]}\end{array}$ & $57 /$ female & $\begin{array}{l}\text { Abdominal pain, } \\
\text { nausea, vomiting and } \\
\text { constipation }\end{array}$ & $\begin{array}{l}\text { The wall of ileum was } \\
\text { thickened }\end{array}$ & $\begin{array}{l}\text { Homogeneous } \\
\text { moderately } \\
\text { enhanced }\end{array}$ & $\begin{array}{l}\text { proximal ileum } \\
\text { significantly } \\
\text { expanded }\end{array}$ & $\begin{array}{l}\text { Multiple small } \\
\text { lymph nodes } \\
\text { adjacent to } \\
\text { mesenteric vessels }\end{array}$ \\
\hline $\begin{array}{l}\text { Mizumoto } \\
\text { et al [34] }\end{array}$ & $54 /$ male & $\begin{array}{l}\text { Abdominal pain and } \\
\text { vomiting }\end{array}$ & $\begin{array}{l}\text { The wall of jejunum was } \\
\text { thickened }\end{array}$ & ND & $\begin{array}{l}\text { Narrow bowel } \\
\text { cavity and } \\
\text { proximal intestinal } \\
\text { dilatation. }\end{array}$ & $\begin{array}{l}\text { A number of small } \\
\text { lymph nodes were } \\
\text { noted beside the } \\
\text { mesenteric vessels. }\end{array}$ \\
\hline $\begin{array}{l}\text { Plowman et } \\
\text { al [35] }\end{array}$ & $41 /$ female & $\begin{array}{l}\text { Persistent abdominal } \\
\text { pain and constipation }\end{array}$ & $\begin{array}{l}\text { The wall of the jejunum was } \\
\text { thickened to the annular } \\
\text { area }\end{array}$ & $\begin{array}{l}\text { Homogeneous } \\
\text { moderately } \\
\text { enhanced }\end{array}$ & $\begin{array}{l}\text { Narrow bowel } \\
\text { cavity and } \\
\text { proximal intestinal } \\
\text { dilatation. }\end{array}$ & ND \\
\hline $\begin{array}{l}\text { Singh et al } \\
{[22]}\end{array}$ & $41 /$ male & $\begin{array}{l}\text { Abdominal pain and } \\
\text { bloating }\end{array}$ & Jejunum ring thickened & $\begin{array}{l}\text { enhanced } \\
\text { homogeneity }\end{array}$ & $\begin{array}{l}\text { proximal intestinal } \\
\text { dilatation }\end{array}$ & $\begin{array}{l}\text { mesenteric roots } \\
\text { with apparent } \\
\text { vascular submasses }\end{array}$ \\
\hline $\begin{array}{l}\text { Choi et al } \\
{[23]}\end{array}$ & $38 /$ male & $\begin{array}{l}\text { Abdominal pain and } \\
\text { diarrhea }\end{array}$ & $\begin{array}{l}\text { An ectogenic mass of ileum } \\
\text { with thickened intestinal } \\
\text { wall, }\end{array}$ & $\begin{array}{l}\text { Homogeneous } \\
\text { moderately } \\
\text { enhanced }\end{array}$ & $\begin{array}{l}\text { proximal intestinal } \\
\text { dilatation }\end{array}$ & $\begin{array}{l}\text { Enlarged } \\
\text { mesenteric lymph } \\
\text { nodes }\end{array}$ \\
\hline $\begin{array}{l}\text { Choi et al } \\
{[23]}\end{array}$ & $48 /$ male & $\begin{array}{l}\text { Diffuse abdominal } \\
\text { pain }\end{array}$ & $\begin{array}{l}\text { The wall of the ileum was } \\
\text { thickened and formed a mass }\end{array}$ & $\begin{array}{l}\text { Homogeneous } \\
\text { moderately } \\
\text { enhanced }\end{array}$ & ND & $\begin{array}{l}\text { Adjacent enlarged } \\
\text { lymph nodes of } \\
\text { intestine and } \\
\text { mesanglial. }\end{array}$ \\
\hline
\end{tabular}

SET: ND \pm no data.

The table indicated that the clinical manifestations of the small intestinal solitary MS in non-leukemia patients were basically abdominal pain and abdominal distension caused by complete or incomplete intestinal obstruction, while the CT manifestations included intestinal lumen stenosis caused by intestinal wall thickening. Contrast enhancement was mainly homogeneous enhancement and mesenteric lymph node enlargement. This was not consistent with the CT manifestations of MS found by Ooi [21] and Meyer et al. [20], which may be due to the MS involving multiple parts of the whole body. Although all the cases collected by Choi et al. [23] were from the gastrointestinal tract, they were mixed with myeloid sarcomas caused by non-leukemia patients. Therefore, it was impossible to analyze and summarize the CT signs of the myeloid sarcomas caused by non-leukemia patients. The 12 cases in table 1 were all in the small intestine and were all non-leukemia patients. The aforementioned data were combined with our own cases and the conclusions led to the speculation that the CT manifestations of isolated small intestinal myeloid cells in non-leukemia patients were the thickening of intestinal wall and the tumor formation. Moreover, we deduced that in such cases, the intestinal cavity was narrow and that the expansion of the proximal small intestine was readily caused, whereas the mesenteric lymph nodes were also affected. The contrast enhancement was mainly homogeneous enhancement. The imaging signs appeared to be different from the $\mathrm{CT}$ findings of patients with inflammatory lesions and lymphoma. The latter requires more cases to support our hypothesis.

\section{Conclusion}

Isolated small intestinal $\mathrm{MS}$ is a rare malignant tumor, which usually appears with intestinal obstruction as the first symptom. The patients who have never had a malignant blood disease are considered a major diagnostic challenge. To 
improve radiologists' awareness of isolated small intestinal MS, MS must be used as the differential diagnosis of small intestinal tumors. There were some limitations in this literature. Firstly, a part of case reports were conference papers so we could not get detail, so we had to give up, and secondly we did not make a clinical or radiological comparison with the articles about the MS patients with myeloid leukemia.

\section{Compliance with Ethical Standards}

This study was approved by the ethics committee of Guangdong Hospital of Traditional Chinese Medicine.

\section{Conflict of Interest}

The authors declare that they have no conflict of interest.

\section{References}

[1] Pui MH, Fletcher BD, Langston JW. Granulocytic sarcoma in childhood leukemia: imaging features. Radiology 1994; 190 (3): 698-702.

[2] Paydas S, Zorludemir S, Ergin M. Granulocytic sarcoma: 32 cases and review of the literature. Leuk Lymphoma 2006; 47 (12): 2527-41.

[3] Pileri SA, Ascani S, Cox MC, Campidelli C, Bacci F, Piccioli $\mathrm{M}$, et al. Myeloid sarcoma: clinico-pathologic, phenotypic and cytogenetic analysis of 92 adult patients. Leukemia 2007; 21 (2): $340-50$.

[4] Yilmaz AF, Saydam G, Sahin F, Baran Y. Granulocytic sarcoma: a systematic review. Am J Blood Res 2013; 3 (4): 265-70.

[5] Neiman RS, Barcos M, Berard C, Bonner H, Mann R, Rydell RE, et al. Granulocytic sarcoma: a clinicopathologic study of 61 biopsied cases. Cancer 1981; 48 (6): 1426-37.

[6] Messager M, Amielh D, Chevallier C, Mariette C. Isolated granulocytic sarcoma of the pancreas: a tricky diagnostic for primary pancreatic extramedullary acute myeloid leukemia. World J Surg Oncol 2012; 10: 13.

[7] Kawamoto K, Miyoshi H, Yoshida N, Takizawa J, Sone H, Ohshima K. Clinicopathological, Cytogenetic, and Prognostic Analysis of 131 Myeloid Sarcoma Patients. Am J Surg Pathol 2016; 40 (11): 1473-83.

[8] Meyer HJ, Ponisch W, Schmidt SA, Wienbeck S, Braulke F, Schramm D, et al. Clinical and imaging features of myeloid sarcoma: a German multicenter study. BMC Cancer 2019; 19 (1): 1150 .

[9] Williams EA, Bowman AW. Multimodality imaging of small bowel neoplasms. Abdom Radiol (NY) 2019; 44 (6): 2089-103.

[10] Reynolds I, Healy P, McNamara DA. Malignant tumours of the small intestine. Surgeon 2014; 12 (5): 263-70.

[11] Yu T, Xu G, Xu X, Yang J, Ding L. Myeloid sarcoma derived from the gastrointestinal tract: A case report and review of the literature. Oncol Lett 2016; 11 (6): 4155-9.
[12] Catalano MF, Levin B, Hart RS, Troncoso P, DuBrow RA, Estey EH. Granulocytic sarcoma of the colon. Gastroenterology 1991; 100 (2): 555-9.

[13] Kohl SK, Aoun P. Granulocytic sarcoma of the small intestine. Arch Pathol Lab Med 2006; 130 (10): 1570-4.

[14] Kitagawa Y, Sameshima Y, Shiozaki H, Ogawa S, Masuda A, Mori SI, et al. Isolated granulocytic sarcoma of the small intestine successfully treated with chemotherapy and bone marrow transplantation. Int J Hematol 2008; 87 (4): 410-3.

[15] Meis JM, Butler JJ, Osborne BM, Manning JT. Granulocytic sarcoma in nonleukemic patients. Cancer 1986; 58 (12): 2697-709.

[16] Yamauchi K, Yasuda M. Comparison in treatments of nonleukemic granulocytic sarcoma: report of two cases and a review of 72 cases in the literature. Cancer 2002; 94 (6): 1739-46.

[17] Antic D, Elezovic I, Milic N, Suvajdzic N, Vidovic A, Perunicic M, et al. Is there a "gold" standard treatment for patients with isolated myeloid sarcoma? Biomed Pharmacother 2013; 67 (1): 72-7.

[18] Hossfeld DK. World Health Organization Classification of Tumours: Pathology and Genetics of Tumours of Haematopoietic and Lymphoid Tissues. Annals of Oncology 2002; 13 (3).

[19] Kumar B, Bommana V, Irani F, Kasmani R, Mian A, Mahajan $\mathrm{K}$. An uncommon cause of small bowel obstruction: isolated primary granulocytic sarcoma. QJM 2009; 102 (7): 491-3.

[20] Meyer HJ, Beimler M, Borte G, Ponisch W, Surov A. Radiological and clinical patterns of myeloid sarcoma. Radiol Oncol 2019; 53 (2): 213-8.

[21] Ooi GC, Chim CS, Khong PL, Au WY, Lie AK, Tsang KW, et al. Radiologic manifestations of granulocytic sarcoma in adult leukemia. AJR Am J Roentgenol 2001; 176 (6): 1427-31.

[22] Singh A, Kumar P, Chandrashekhara SH, Kumar A. Unravelling chloroma: review of imaging findings. Br J Radiol 2017; 90 (1075): 20160710.

[23] Choi EK, Ha HK, Park SH, Lee SJ, Jung SE, Kim KW, et al. Granulocytic sarcoma of bowel: CT findings. Radiology 2007; 243 (3): 752-9.

[24] Shinagare AB, Krajewski KM, Hornick JL, Zukotynski K, Kurra V, Jagannathan JP, et al. MRI for evaluation of myeloid sarcoma in adults: a single-institution 10-year experience. AJR Am J Roentgenol 2012; 199 (6): 1193-8.

[25] Aschoff P, Hantschel M, Oksuz M, Werner MK, Lichy M, Vogel W, et al. Integrated FDG-PET/CT for detection, therapy monitoring and follow-up of granulocytic sarcoma. Initial results. Nuklearmedizin 2009; 48 (5): 185-91.

[26] Ueda K, Ichikawa M, Takahashi M, Momose T, Ohtomo K, Kurokawa M. FDG-PET is effective in the detection of granulocytic sarcoma in patients with myeloid malignancy. Leuk Res 2010; 34 (9): 1239-41.

[27] Chandra P, Dhake S, Purandare N, Agrawal A, Shah S, Rangarajan V. Role of FDG PET/CT in Diagnostic Evaluation of Granulocytic Sarcomas: A Series of 12 Patients. Indian J Nucl Med 2017; 32 (3): 198-202. 
[28] Palanivelu C, Rangarajan M, Senthilkumar R, Annapoorni S. Laparoscopic management of an obstructing granulocytic sarcoma of the jejunum causing intussusception in a nonleukemic patient: report of a case. Surg Today 2009; 39 (7): 606-9.

[29] Yoldas T, Erol V, Demir B, Hoscoskun C. A rare cause of mechanical obstruction: Intestinal myeloid sarcoma. Ulus Cerrahi Derg 2014; 30 (3): 176-8.

[30] Lee SY, Park SJ, Kim YH, Lee JH. Nonleukemic granulocytic sarcoma presenting as intussusception of small bowel. Int $\mathrm{J}$ Clin Oncol 2008; 13 (5): 467-70.

[31] S. Cicilet, F. K. Tom, B. Philip, A. Biswas. Primary myeloid sarcoma of small bowel. BMJ Case Rep 2017.

[32] Wang P, Li Q, Zhang L, Ji H, Zhang CZ, Wang B. A myeloid sarcoma involving the small intestine, kidneys, mesentery, and mesenteric lymph nodes: A case report and literature review. Medicine (Baltimore) 2017; 96 (42): e7934.

[33] Aslan B, Tuney D, Ercetin Y, Bozkurt SU, Uprak TK. De novo myeloid sarcoma as a rare cause of small bowel obstruction: CT findings and histopathologic correlation. Radiol Case Rep 2019; 14 (12): 1487-90.

[34] Mizumoto R, Tsujie M, Wakasa T, Kitani K, Manabe H, Fukuda S, et al. Isolated myeloid sarcoma presenting with small bowel obstruction: a case report. Surg Case Rep 2020; 6 (1): 2 .

[35] Plowman RS, Nguyen BD. Gastrointestinal: Small bowel and mesenteric primary myeloid sarcoma: PET/CT imaging. J Gastroenterol Hepatol 2016; 31 (5): 907. 